\title{
Yield and yield components of wheat as affected by different seed rates and nitrogen levels
}

\author{
Wajid Ali Shah ${ }^{1}$, Zafar Hayat ${ }^{1}$, Roohul Amin ${ }^{1}$, Shazma Anwar ${ }^{2}$, \\ Muhammad Islam ${ }^{2 *}$ and Anjum² \\ 1. Department of Agronomy, Bacha Khan University, Charsadda-Pakistan \\ 2. Department of Agronomy, University of Agriculture, Peshawar-Pakistan \\ *Corresponding author's e-mail: islamswati439@yahoo.com
}

Citation

Wajid Ali Shah, Zafar Hayat, Roohul Amin, Shazma Anwar, Muhammad Islamand and Anjum. Yield and yield components of wheat as affected by different seed rates and nitrogen levels. Pure and Applied Biology. Vol. 5, Issue 3, pp547-553. http://dx.doi.org/10.19045/bspab.2016.50070

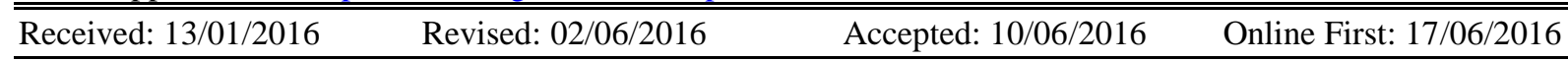

\section{Abstract}

An experiment was conducted to study yield and yield components of wheat under different seed rates and nitrogen levels. Five seed rates $\left(S_{1}=60 \mathrm{~kg} \mathrm{ha}^{-1}, S_{2}=80 \mathrm{~kg} \mathrm{ha}^{-1}, \mathrm{~S}_{3}=100 \mathrm{~kg}\right.$ $\mathrm{ha}^{-1}, \mathrm{~S}_{4}=120 \mathrm{~kg} \mathrm{ha}^{-1}$ and $\left.\mathrm{S}_{5}=140 \mathrm{~kg} \mathrm{ha}^{-1}\right)$ and five nitrogen levels $\left(\mathrm{N}_{0}=\right.$ Control, $\mathrm{N}_{1}=40 \mathrm{~kg}$ $\mathrm{ha}^{-1}, \mathrm{~N}_{2}=80 \mathrm{~kg} \mathrm{ha}^{-1}, \mathrm{~N}_{3}=120 \mathrm{~kg} \mathrm{ha}^{-1}$ and $\mathrm{N}_{5}=140 \mathrm{~kg} \mathrm{ha}^{-1}$ ) were tested in the experiment. Results showed that maximum tillers $\mathrm{m}^{-2}$ (334), leaf area index (4.50), grains spike ${ }^{-1}(60)$, 1000 -grains weight (41.91 g), grain yield (3957 $\left.\mathrm{kg} \mathrm{ha}^{-1}\right)$ and biological yield (10172 $\left.\mathrm{kg} \mathrm{ha}^{-1}\right)$ was produced by the plots seeded with $120 \mathrm{~kg} \mathrm{ha}^{-1}$. Similarly nitrogen fertilization at the rate of $120 \mathrm{~kg} \mathrm{ha}^{-1}$ resulted maximum (348) tillers $\mathrm{m}^{-2}$, leaf area index (4.42) grains spike ${ }^{-1}$ (63), 1000 -grain weight (42.19 g), grain yield (4145 kg ha-1) and biological yield (10579 kg ha-1). In case of interaction between seed arte and nitrogen it was observed that maximum tillers $\mathrm{m}^{-}$ ${ }^{2}$, leaf area index, grains spike ${ }^{-1}, 1000$-grain weight, grain yield and biological yield was produced by plots received seed at the rate of $120 \mathrm{~kg} \mathrm{ha}^{-1}$ and nitrogen with $120 \mathrm{~kg} \mathrm{ha}^{-1}$, while maximum leaf area index was recorded from the plots seeded with $120 \mathrm{~kg} \mathrm{ha}^{-1}$ and fertilized with $80 \mathrm{~kg} \mathrm{~N} \mathrm{ha}^{-1}$.

Key words: Wheat; Seed rates; Nitrogen levels; Yield and yield components

\section{Introduction}

Nitrogen has long been recognized as a critical nutrient for wheat [1]. Work established adequate nutrient levels for crops has usually involved in whole canopy analysis [2, 3], but researchers have increasingly recognized the importance and utility of analyzing individual plant components at various stages of growth to better understand how wheat develops and grows $[3,5]$. Analysis of individual plant components, when done, has almost exclusively been based on pooling basic tissue types such as leaves, stems, and kernels from all shoots within the canopy. With the development of morphological naming schemes that uniquely identify each plant component [6] researchers can now communicate with greater detail and precision about phenomena occurring during wheat growth and development. The basic tissue types of leaves, stems, and kernels can now be partitioned as part of individually identified culms or as parts of phytomers. Phytomers are the fundamental building block of culms consisting of a node and tissues developed from it, including the 
blade, sheath, internode, and axillary bud. An advantage of this approach is that the canopy can be considered a dynamic population of culms or phytomers appearing, growing, interacting, and senescing over time, with the final result determining crop yield $[5,7]$.

Plant density is one of the major factors determining the ability of the crop to capture resources. It is of particular importance in wheat production because it is under the farmer's control in most cropping systems. Optimum plant densities vary greatly between areas according to climatic conditions, soil, sowing time, and varieties. Consequently, there is a value in defining relationships between density and wheat yield to establish optimum seeding rates for various agro-climatic regions. The difference in seed rates giving maximum yields cannot attribute to differences in the plant population established from the weight of the seed sown, but other factors may be involved. Greater plant population can be obtained from higher seed rates, but would give poor growth and development of the crop which will ultimately have adverse effect on the number of ear bearing or productive tillers, number of grain spike ${ }^{-1}$, spike length, number of spiklets spike $^{-1}$, grain weight and finally the grain yield. However, with too low seed rate all these characters may not be able to compensate for the effect of reduced spike population, though wheat has the ability to adjust the variation in seed rates within certain limits, use of low seed rates do not produce the required number of plants in the field that could efficiently utilize light, water and nutrients and thus result in low yield. Use of maximum seed rates may cause lodging, exhaustion of nutrients and water before maturity and may provide favorable condition for insect pest and disease incidence.

Keeping in view the importance of optimum seed rate and nitrogen level, the present study was designed to find out the effect of different seed rates and nitrogen levels on wheat production.

\section{Materials and methods}

Yield and yield components of wheat as affected by different seed rates and nitrogen levels were studied in a field experiment. The experiment was laid out in randomized complete block design (split plot arrangement) having four replications. The sub plot size of $4 \times 1.8 \mathrm{~m}^{2}$ (having 6 rows, $30 \mathrm{~cm}$ apart) was maintained. Prior to sowing, a composite soil sample from the experimental area up to $30 \mathrm{~cm}$ depth was collected and analyzed for physicochemical characteristics. The soils of the site were clay in texture having on an average $\mathrm{N}(0.42 \%), \mathrm{P}_{2} \mathrm{O}_{5}(6.22 \mathrm{ppm})$ and $\mathrm{K}_{2} \mathrm{O}(97.75 \mathrm{ppm})$. Seed rates $\left(\mathrm{S}_{1}=60 \mathrm{~kg}\right.$

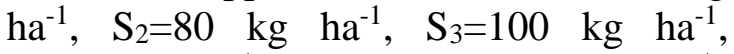
$\mathrm{S}_{4}=120 \mathrm{~kg} \mathrm{ha}^{-1}, \quad \mathrm{~S}_{5}=140 \quad \mathrm{~kg} \quad \mathrm{ha}^{-1}$ ) were allotted to main plots, whereas nitrogen levels $\left(\mathrm{N}_{0}=\right.$ Control, $\mathrm{N}_{1}=40 \mathrm{~kg}$ $\mathrm{ha}^{-1}, \mathrm{~N}_{2}=80 \mathrm{~kg} \mathrm{ha}^{-1}, \mathrm{~N}_{3}=120 \mathrm{~kg} \mathrm{ha}^{-1}$, $\mathrm{N}_{4}=140 \mathrm{~kg} \mathrm{ha}^{-1}$ ) to sub plots. Wheat variety Lakki- J03 was sown on a well prepared seed bed. Various seed rates were used and the crop was sown on the same calendar day of sowing. Phosphorus was applied at the rate of $90 \mathrm{~kg} \mathrm{ha}^{-1}$ in the form of Single super phosphate (SSP) and urea was used as a nitrogen source. All phosphorus doses were used during sowing time. While nitrogen was applied in two split doses i.e. $50 \% \mathrm{~N}$ at sowing time and $50 \%$ at tillering stage. All other agronomic practices were maintained constant. Data was recorded on number of tillers $\mathrm{m}^{-2}$, grains spike ${ }^{-1}$, leaf area index, 1000-grains weight $(\mathrm{g})$, biological yield $\left(\mathrm{kg} \mathrm{ha}^{-1}\right)$ and grain $\left(\mathrm{kg} \mathrm{ha}^{-1}\right)$. For number of tillers three central rows of one meter length were counted. Grains spike ${ }^{-1}$ data were calculated by average of five spikes randomly selected in each sub plot. Leaf area index was determined by dividing leaf area tiller ${ }^{-1}$ by ground area. Thousand grains weight recorded by using electrical balance. At maturity three rows of the plot were harvested and tied into small bundle for sun drying, the dried bundles were 
used for noting biological yield and after that threshed for of grain yield. Statistical analysis of the two years data was done at $1 \%$ level of probability using Duncan's Multiple Range Test (DMRT) to test the difference between the individual means. [8].

\section{Results and discussion}

Tillers $\mathbf{~ m}^{-2}$

Data presented in table 1 indicated that tillers $\mathrm{m}^{-2}$ of wheat significantly affected by seed rates and nitrogen levels. More tillers $\mathrm{m}^{-2}$ (334) were counted in plots received seed at the rate of $120 \mathrm{~kg} \mathrm{ha}^{-1}$, while less number of tillers $\mathrm{m}^{-2}$ (280) were recorded when $60 \mathrm{~kg} \mathrm{ha}^{-1}$ seed rate was used. The tillering potential was much higher at optimum seed rate, when compared to low or high seed rate. Maximum tillers at higher seed rates then at lower seed rates were reported by [9, 11]. Regarding nitrogen application number of tillers increased with each increment in nitrogen level. Maximum tillers $\mathrm{m}^{-2}$ (348) were recorded in plots treated with $\mathrm{N}$ at rate of $120 \mathrm{~kg} \mathrm{ha}{ }^{-1}$, followed by $140 \mathrm{~kg} \mathrm{~N} \mathrm{ha}{ }^{-1}$, while minimum tillers $\mathrm{m}^{-2}$ (235) were recorded in control plots (received no nitrogen). This increase might be due to increased nitrogen rate up to some level, therefore, led to greater stimulation of vegetative growth. All fertilizer levels significantly affected vegetative growth of the plant depending upon the availability of needed nutrition which leads to proportional increase in tillers $\mathrm{m}^{-2}[12,13]$. The interactive effect of seed rate and nitrogen levels was also found significant

(Figure 1a). Plots received seed at the rate $120 \mathrm{~kg} \mathrm{ha}^{-1}$ and $120 \mathrm{~kg} \mathrm{~N} \mathrm{ha}^{-1}$ produced more tillers $\mathrm{m}^{-2}$ whereas less tillers $\mathrm{m}^{-2}$ were counted in plots treated with $60 \mathrm{~kg}$ $\mathrm{ha}^{-1}$ seed rate in control plots $\left(0 \mathrm{~kg} \mathrm{~N} \mathrm{ha}^{-1}\right)$.

Table 1. Tillers $\mathrm{m}^{-2}$, leaf area index and number of grains spike $\mathrm{e}^{-1}$ of wheat as affected by different seed rate and nitrogen levels

\begin{tabular}{|l|c|c|c|}
\hline Treatments & Tillers $\mathbf{~ m}^{-2}$ & Leaf area index & $\begin{array}{c}\text { Number of grains } \\
\text { spike-1 }^{-1}\end{array}$ \\
\hline A: Seed rate & & & \\
\hline $\mathrm{S}_{1}\left(60 \mathrm{~kg} \mathrm{ha}^{-1}\right)$ & $280.50 \mathrm{~d}$ & $3.17 \mathrm{~d}$ & $51.25 \mathrm{~d}$ \\
\hline $\mathrm{S}_{2}\left(80 \mathrm{~kg} \mathrm{ha}^{-1}\right)$ & $300.40 \mathrm{c}$ & $3.54 \mathrm{c}$ & $55.85 \mathrm{c}$ \\
\hline $\mathrm{S}_{3}\left(100 \mathrm{~kg} \mathrm{ha}^{-1}\right)$ & $301.75 \mathrm{c}$ & $3.91 \mathrm{~b}$ & $58.55 \mathrm{~b}$ \\
\hline $\mathrm{S}_{4}\left(120 \mathrm{~kg} \mathrm{ha}^{-1}\right)$ & $334.85 \mathrm{a}$ & $4.50 \mathrm{a}$ & $60.80 \mathrm{a}$ \\
\hline $\mathrm{S}_{5}\left(140 \mathrm{~kg} \mathrm{ha}^{-1}\right)$ & $322.40 \mathrm{~b}$ & $3.38 \mathrm{~cd}$ & $59.35 \mathrm{~b}$ \\
\hline $\mathbf{L S D}(\mathbf{P} \leq \mathbf{0 . 0 5}$ & $\mathbf{1 2 . 3 2}$ & $\mathbf{0 . 2 7}$ & $\mathbf{1 . 3 5}$ \\
\hline B: $\mathbf{N i t r o g e n ~ l e v e l s}$ & & & $49.45 \mathrm{e}$ \\
\hline $\mathrm{N}_{0}(\mathrm{Control})$ & $235.30 \mathrm{~d}$ & $2.12 \mathrm{~d}$ & $54.20 \mathrm{~d}$ \\
\hline $\mathrm{N}_{1}\left(40 \mathrm{~kg} \mathrm{ha}^{-1}\right)$ & $291.55 \mathrm{c}$ & $3.65 \mathrm{c}$ & $56.90 \mathrm{c}$ \\
\hline $\mathrm{N}_{2}\left(80 \mathrm{~kg} \mathrm{ha}^{-1}\right)$ & $320.15 \mathrm{~b}$ & $4.03 \mathrm{~b}$ & $63.90 \mathrm{a}$ \\
\hline $\mathrm{N}_{3}\left(120 \mathrm{~kg} \mathrm{ha}^{-1}\right)$ & $348.00 \mathrm{a}$ & $4.42 \mathrm{a}$ & $61.35 \mathrm{~b}$ \\
\hline $\mathrm{N}_{4}\left(140 \mathrm{~kg} \mathrm{ha}^{-1}\right)$ & $\mathbf{1 1 . 1 4}$ & $4.27 \mathrm{a}$ & $\mathbf{2 . 1 8}$ \\
\hline LSD $(\mathbf{P} \leq \mathbf{0 . 0 5})$ & & $\mathbf{0 . 1 7}$ & \\
\hline C: $\mathbf{I n t e r a c t i o n}(\mathbf{A} \mathbf{x})$ & $\mathbf{2 1 . 7 0}$ & & $\mathbf{4 . 2 6}$ \\
\hline LSD $(\mathbf{P} \leq \mathbf{0 . 0 5})$ & & $\mathbf{0 . 3 9}$ & \\
\hline
\end{tabular}

Means followed by different letters are significantly different from one another at $\mathrm{P} \leq 0.05$

\section{Leaf area index}

Data given in table 1 indicated that seed rate and nitrogen application significantly affected leaf area index. Maximum LAI (4.10) was recorded when plots were seeded with $120 \mathrm{~kg} \mathrm{ha}^{-1}$, while $60 \mathrm{~kg} \mathrm{ha}^{-1}$ seed rate resulted minimum LAI (2.76). This might be due to long vegetation growth in low seeded plots than higher seeded ones. The seeding rate at $140 \mathrm{~kg} \mathrm{ha}^{-}$ 
1 decreased the leaf area index due to greater competition among the plants for the limited sunlight and available nutrients in the soil. Nitrogen application had also a significant effect on LAI. Maximum LAI (4.03) was noted when $120 \mathrm{~kg} \mathrm{~N} \mathrm{ha}^{-1}$ was used, while minimum LAI (2.92) was recorded with no nitrogen application. Regarding the interactive effect, LAI increased with increase in seed rates and nitrogen levels (Figure 1b). Highest LAI was recorded when $120 \mathrm{~kg} \mathrm{ha}^{-1}$ seed rate and $120 \mathrm{~kg} \mathrm{~N} \mathrm{ha}^{-1}$ was used, while less LAI was found in plots supplied with 60 $\mathrm{kg} \mathrm{ha}^{-1}$ seed rate in control plots.

\section{Number of grains spike ${ }^{-1}$}

The potential of wheat spike is determined by the number of grains spike ${ }^{-1}$ which is an important yield component of grain yield. Statistical analysis of the data indicated that seed rate and nitrogen application had a significant effect on number of grains spike $^{-1}$ (Table 1). Plots seeded with $120 \mathrm{~kg}$ $\mathrm{ha}^{-1}$ seed rate produced more grains spike ${ }^{-1}$ (60), whereas $60 \mathrm{~kg} \mathrm{ha}^{-1}$ seed rate resulted less number of grains spike ${ }^{-1}$ (51). Higher seed rates produced significant decrease in the number of grains $\operatorname{spike}^{-1}[9,10,14]$. Grains spike ${ }^{-1}$ also increased with increase in nitrogen levels up to a certain limit. More grains (63) spike ${ }^{-1}$ were produced by the plots $120 \mathrm{~kg} \mathrm{~N} \mathrm{ha}^{-1}$, while less grains spike $^{-1}$ (49) were recorded control plots. These results are in agreement with [15], who reported that grains spike ${ }^{-1}$ increased at $120 \mathrm{~kg} \mathrm{~N} \mathrm{ha-1}$. In case of $\mathrm{S} \times \mathrm{N}$ interaction, more number of grains spike ${ }^{-1}$ were counted in plots treated with $120 \mathrm{~kg}$ $\mathrm{ha}^{-1}$ seed rate and $120 \mathrm{~kg} \mathrm{~N} \mathrm{ha}{ }^{-1}$ (Figure1c). These findings are in conformity with the results of [16], who also found that the indication of seed rate and nitrogen levels had significant effect on grains spike ${ }^{-1}$.

\section{Thousand grains weight (g)}

Table 2 revealed that thousand grains weight of wheat considerably affected by seed rates and nitrogen levels. Maximum 1000-grains weight (41.91 g) was recorded when plots were seeded with $120 \mathrm{~kg} \mathrm{ha}^{-1}$.
Further increase in seed rate decreased thousand grains weight and the minimum 1000 -grain weight $(38.30 \mathrm{~g})$ was recorded when $60 \mathrm{~kg} \mathrm{ha}^{-1}$ seed rate was used. The reduced grain weight with higher seed rate might be due to greater competition among plants in plots seeded at the highest rate as compared to plants in plots where less seed rate was used These results are in conformity with [14, 17], who also reported that 1000 grains weight decreased with increasing in seeding densities. Regarding N levels, heavier (42.19 g) grain were noted when $120 \mathrm{~kg} \mathrm{~N}^{-1}$ was used, while lighter grains (37.38 g) were recorded with no nitrogen fertilizer. These results are in agreement with those of [18]. The interaction between seed rate and nitrogen levels was also found significant (Figure $1 \mathrm{~d}$ ). Maximum 1000-grain weight was noted when $120 \mathrm{~kg} \mathrm{ha}^{-1}$ seed rate and $120 \mathrm{~kg} \mathrm{~N} \mathrm{ha}^{-1}$ was used, while minimum 1000 -grain weight was noted from plots in which seed rate was used $60 \mathrm{~kg} \mathrm{ha}^{-1}$ in control plots. These results are in conformity with [14].

\section{Grain yield $\left(\mathrm{kg} \mathrm{ha}^{-1}\right)$}

Data presented in table 2 indicated that grain yield was significantly affected by different seed rates and nitrogen. Maximum grain yield (3957 kg ha-1) was found in plots seeded with $120 \mathrm{~kg} \mathrm{ha}^{-1}$, while minimum grain yield $\left(2784 \mathrm{~kg} \mathrm{ha}^{-1}\right)$ was recorded in plots in which $60 \mathrm{~kg} \mathrm{ha}^{-1}$ seeds were sown. These results are in agreement with $[9,10,11,19,20,21]$ who reported that grain yield increased as seed rate increased and the highest grain yield was noted in plots seeded at the rate of 120 $\mathrm{kg} \mathrm{ha}{ }^{-1}$. Data further revealed that grain yield was significantly affected by different nitrogen levels. Plots treated with $120 \mathrm{~kg} \mathrm{~N} \mathrm{ha}^{-1}$ produced maximum grain yield (4145 kg ha $\left.{ }^{-1}\right)$, while minimum (2479 $\mathrm{kg} \mathrm{ha}^{-1}$ ) was recorded in control plots. This might be due to adequate supply of nutrients during grain filling duration. Grain yield increased with increasing $\mathrm{N}$ rate up to some level [18]. Regarding the interaction between seed 
rate and nitrogen levels grain yield increased with increase in seed rate up to $120 \mathrm{~kg} \mathrm{ha}^{-1}$ and $\mathrm{N}$ up to $120 \mathrm{~kg} \mathrm{ha}^{-1}$ (Figure 1e). Similar results were found by [22].

\section{Biological yield ( $\left.\mathrm{kg} \mathrm{ha}^{-1}\right)$}

Biological yield of wheat considerably affected by seed rates and nitrogen levels.

(Table 2). Maximum biological yield (10172 kg ha ${ }^{-1}$ ) was noted when plots were seeded with $120 \mathrm{~kg} \mathrm{ha}^{-1}$, followed by plots seeded with 80 and $140 \mathrm{~kg} \mathrm{ha}^{-1}$, while minimum biological yield (8738 $\mathrm{kg} \mathrm{ha}^{-1}$ ) was recorded when $60 \mathrm{~kg} \mathrm{ha}^{-1}$ seed rate was used. These results are in agreement with [14], who stated that the increase in biological yield with higher seed rate might be due to more number of plants per unit area, though with reduced tillers. In case if nitrogen levels, maximum (10579
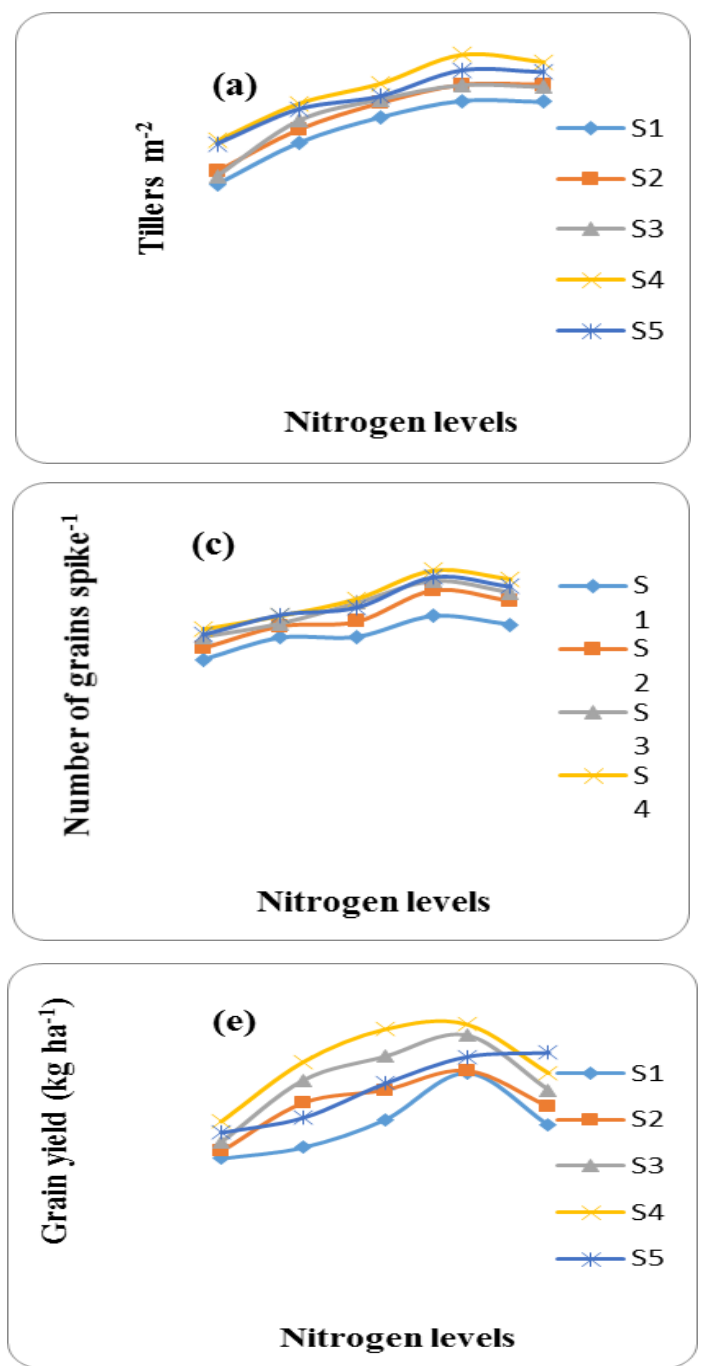

Figure 1. Tillers $\mathbf{m}^{-2}$, leaf area index, $\mathrm{kg} \mathrm{ha}^{-1}$ ) biological yield was noted when $120 \mathrm{~kg} \mathrm{~N} \mathrm{ha}^{-1}$ was used, while minimum biological yield $\left(7615 \mathrm{~kg} \mathrm{ha}^{-1}\right)$ were recorded in control plots. Increase in biological yield with increase in nitrogen levels may be due to the effect of nitrogen on vegetative growth of wheat as well as increase in tillers number with higher rates of nitrogen. These results are in conformity with [15], who stated that biological yield and most grain yield components increased with $120 \mathrm{~kg} \mathrm{~N} \mathrm{ha}^{-1}$. The data also indicated that interaction between seed rate and nitrogen levels was also found significant effect (Figure 1f). Data showed that biological yield increased up to the seed rate of $120 \mathrm{~kg} \mathrm{ha}^{-1}$ and also $\mathrm{N}$ up to $120 \mathrm{~kg} \mathrm{ha}^{-1}$.
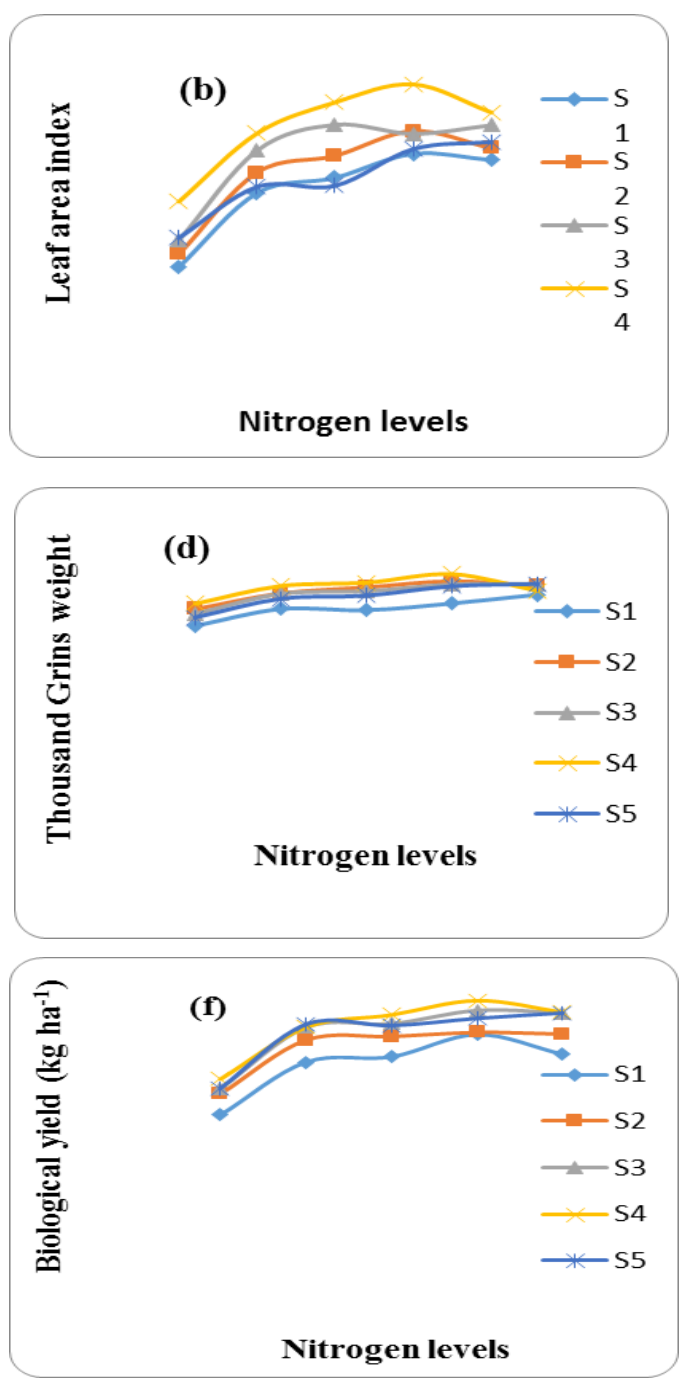
number of grains spike $^{-1}$, thousand grains weight, grain yield and biological yield of wheat as affected by seed rates and nitrogen levels

Table 2. 1000-grains weight, grain yield and biological yield of wheat as affected by different seed rate and nitrogen levels

\begin{tabular}{|c|c|c|c|}
\hline Treatments & $\begin{array}{c}\text { 1000-grains } \\
\text { weight (g) }\end{array}$ & Grain yield (kg ha-1) & $\begin{array}{c}\text { Biological yield (kg } \\
\text { ha }^{-1} \text { ) }\end{array}$ \\
\hline $\begin{array}{l}\text { A: Seed rates } \\
S_{1}\left(60 \quad \mathrm{~kg} \mathrm{ha}^{-1}\right)\end{array}$ & $38.30 \mathrm{~d}$ & $2784.03 \mathrm{c}$ & $8738.45 \mathrm{c}$ \\
\hline $\mathrm{S}_{2}\left(80 \mathrm{~kg} \mathrm{ha}^{-1}\right)$ & $41.23 \mathrm{ab}$ & $3169.43 \mathrm{bc}$ & $9417.65 b$ \\
\hline $\mathrm{S}_{3}\left(100 \mathrm{~kg} \mathrm{ha}^{-1}\right)$ & $40.90 \mathrm{bc}$ & $3608.33 \mathrm{ab}$ & $10006.15 \mathrm{a}$ \\
\hline $\mathrm{S}_{4}\left(120 \mathrm{~kg} \mathrm{ha}^{-1}\right)$ & $41.91 \mathrm{a}$ & $3957.64 \mathrm{a}$ & $10172.40 \mathrm{a}$ \\
\hline $\mathrm{S}_{5}\left(140 \mathrm{~kg} \mathrm{ha}^{-1}\right)$ & $40.40 \mathrm{c}$ & $3459.72 \mathrm{ac}$ & $10094.05 \mathrm{a}$ \\
\hline LSD $(P \leq 0.05)$ & 0.79 & 677.60 & 382.60 \\
\hline \multicolumn{4}{|l|}{ B: Nitrogen levels } \\
\hline $\mathrm{N}_{0}($ Control $)$ & $37.38 \mathrm{c}$ & $2479.17 \mathrm{c}$ & $7615.90 \mathrm{c}$ \\
\hline $\mathrm{N}_{1}\left(40 \mathrm{~kg} \mathrm{ha}^{-1}\right)$ & $40.43 \mathrm{~b}$ & $3209.72 b$ & $9861.20 \mathrm{~b}$ \\
\hline $\mathrm{N}_{2}\left(80 \mathrm{~kg} \mathrm{ha}^{-1}\right)$ & $40.90 \mathrm{~b}$ & $3700.69 \mathrm{ab}$ & $10046.40 \mathrm{~b}$ \\
\hline $\mathrm{N}_{3}\left(120 \mathrm{~kg} \mathrm{ha}^{-1}\right)$ & $42.19 \mathrm{a}$ & $4145.14 \mathrm{a}$ & $10579.75 \mathrm{a}$ \\
\hline $\mathrm{N}_{4}\left(140 \mathrm{~kg} \mathrm{ha}^{-1}\right)$ & $41.85 \mathrm{a}$ & $3444.43 \mathrm{~b}$ & $10225.45 \mathrm{ab}$ \\
\hline LSD $(P \leq 0.05)$ & 0.79 & 571.00 & 273.90 \\
\hline \multicolumn{4}{|l|}{ C: Interaction (A x B) } \\
\hline LSD $(P \leq 0.05$ & 1.54 & 1277.00 & 612.50 \\
\hline
\end{tabular}

Means followed by different letters are significantly different from one another at $\mathrm{P} \leq 0.05$

\section{Authors' contributions}

Conceived and designed the experiments: WA Shah \& S Anwar, Performed the experiments: WA Shah, Data collection and field inspection: WA Shah, Z Hayat \& R Amin, Statistical analysis of data: WA Shah, S Anwar, M Islam \& Anjum, Contributed reagents/ materials/ analysis tools: Z Hayat \& R Amin, Wrote the paper: WA Shah \& S Anwar.

\section{References}

1. Miller EC (1939). A physiological study of the winter wheat plant at different stages of its development. Kansas Agric Exp Stn Tech Bull 47.

2. Melsted SW, Motto HL \& Peck TR (1969). Critical plant nutrient composition values useful in interpreting plant analysis data. Agron J. 61:17-20.

3. Baker JM \& Tucker BB (1973). Critical N, P and $\mathrm{K}$ levels in winter wheat. Commun Soil Sci Plant Anal. 4:347-358.

4. Karlen DL \& Whitney DA (1980). Dry matter accumulation, mineral concentrations, and nutrient distribution in winter wheat. Agron J. 72:281-288.

5. McMaster GS, Morgan JA \& Wilhelm WW (1992). Simulating winter wheat spike development and growth. Agric and Forest Metrology 60 (3-4): 193200. (Field Crops Absts 46 (4): 19932042.)

6. Wilhelm WW \& McMaster GS (1996). Spikelet and floret naming scheme for grasses with a spike inflorescence. Crop Sci. 36:1071-1073.

7. Harper JL (1977). Population biology of plants. Academic Press, London Hector, JM (1936). Introduction to the Botany of field crops. Johamnnesburg, 
S. Africa, Central News Agency. 1: 520.

8. Steel RGD \& Torrie JH (1984). Principles and procedure of statistics 2nd ed. Mc Graw Hill, New York.

9. Chatha M, Ahmad R, Mukhtar \& Gill MA (1986). Yield of wheat cultivars as affected by different seed rates under irrigated conditions. Pak J Agric 7 (4): 241-24.

10. Nazir SM, Zafar I, Ghazanfar A \& Akhtar M (1982). Response of wheat to soil moisture stress at early growth stage on high water table soil of Faislabad. J Agric. 83(86): 593-603.

11. Ibrar K (1999). Effect of seed rates and nitrogen levels on wheat. M.Sc (Hons) thesis, Deptt Agro NWFP Agric Uni Peshawar, Pakistan.

12. Rajput FKM, Arian AS, Rajput MJ, Aslam SM \& Baloch AW (1989). The growth and yield of wheat as affected by different seed rates and row spacing. Sarhad J Agric. 5: 479-482.

13. Ayoub M, Lussier S \& Smith DL (1994). Timing and level of Nitrogen fertility effects on spring wheat yield Eastern Canada Crop. Sci. 34: 748756.

14. Marwat AQ, Khalil SK, Latif AW \& Iqbal M (1989). Effect of land preparation and seeding rates on plant height and straw yield on wheat. Sarhad J Agric. 5 (3): 273-278.

15. Geleto T, Tanner DG, Mamo $\mathrm{T} \&$ Gebeyehu G (1995). Response of rainfed bread and durum wheat to source, level and timings of nitrogen fertilization on two Ethiopian vertisols.
Comm. Soil Science and Plant analysis. 26 (11): 17773-17794.

16. Attarde DR \& Khuspe VS (1989). Response of wheat varieties to different levels of seed rate and nitrogen. J Maharashtra Agric Univ. 4: 309-310.

17. Sheikh SM, Ghazanfar MA \& Nazir MS (1985). Growth and yield of three wheat varieties as influenced by different row spacing. Paki J Agric. 6 (3): 146-149.

18. Memon GH, Bughio NH \& Jamro GH (1989). A study on the optimum nitrogen level for proper growth and yield of late sown wheat under sindh conditions, Sarhad J Agric 5 (2): 125127.

19. Mujahid ZH (1972). Effect of row spacing and seed rates on the growth and yield of wheat variety Chenab-70. M. Sc. Agric. Thesis. Agric Uni Faisalbad.

20. Hameed E, Wajid SA, Shad AA, Bakht J \& Muhammad T (2003). Effect of different planting dates, seed rates and nitrogen levels on wheat. Asian J Plant Sci. 2(6): 464-474.

21. Ejaz H, Taj FH, Bakht J, Wajid SA \& Shad AA (2002). Yield and yield components of wheat as affected by different planting dates seed rate and nitrogen levels. Asian J Plant Sci. 1(5): 502-506.

22. Farooq R, Sial A \& Makhdum MI (1989). Effect of timing and different doses of nitrogen fertilizer on yield of wheat. Pak J Agric. 10 (2): 112-115. 